\title{
Financial Decision and Its Relationship with Economic Value Added
}

\author{
Milka E. Escalera-Chávez
}

Research Professor at Multidisciplinary Unit of the Center Zone at Universidad Autónoma de San Luis Potosí Email: milkaech@uas/p.mx

\section{Carlos A. Rojas-Kramer *}

Research Professor at Administrative-Economic Research Center, Universidad Cristóbal Colón Email: crk@ucc.mx

\section{Arturo García-Santillán}

Visiting Scholar at University Center for Economic and Managerial Sciences, Universidad de Guadalajara \&Research Professor at Administrative-Economic Research Center. Universidad Cristóbal Colón Email: arturogarciasantillan@yahoo.com.mx

\section{Doi:10.5901/mjss.2015.v6n1p278}

\section{Abstract}

The aim of this study is to analyze the relationship between financial decisions making from the perspective of the owners or managers of small and medium-sized enterprises (SME) with the creation of economic value for the enterprise. The results obtained from $X^{2}$ (chi-square), indicates that there is sufficient evidence in the sample to prove that from the perspective of the owners or managers of SME, financial decisions are an instrument which promotes growth in the business, and increases value for shareholders. The study shows that both, owner and manager make financial decisions in the enterprise, but in regard to choosing and developing actions that create value, they tend to be different.

Keywords: small and medium enterprises, economic value added, owners, managers.

\section{Introduction}

Currently, it is palpable in every organization, regardless of its size, that the creation of value is not only, an element of competitiveness, but a matter of survival for any enterprise that wants to stay in the market (Roztocki \& LaScola, 2000).

Applied to the field of small and medium-sized enterprises (SME), creation of value is a challenge faced by organizations, as owners or managers are forced to make appropriate financial decisions that contribute to the management of operations in order to achieve the enterprise to create value, and also ponder the activities that destroy value by preventing the growth of the enterprise (Spivey \& McMillan, 1999).

The SME shows differential features that challenge, at first, not only the validity of transcendental action lines regarding how their businesses can create value, but also about the activities currently being done, or that could be made, and potentially affect the value of their business.

The creation of value not only involves the making of decisions related to planning of activities and control of realization of the same, but also considers those involving new investments and the selection of required financing sources, as these may generate or destroy value. So, it is important to consider how the decision making is perceived by the owner or manager as it brings effort, creativity, and attitude.

In this sense, Ochoa (2002) notes that the ability to generate value is not a purely financial matter. He finds its roots in anthropology; on the characteristics of the person who runs the enterprise: its principles, habits, customs, values, and their willingness to compromise.

Value creation is necessary for all types of businesses. In SME, it becomes an element of competitiveness and economic development. For this reason, this study focuses on analyzing the relationship between financial decisions making from the perspective of the owners or managers of the SME with the creation of economic value for the enterprise. The main objective of this work is to corroborate that SME's competitiveness is directly related to economic value added. The relevance of this objective arises from the need for identifying factors affecting SME's competitiveness. 
Such need was pointed out by Kadosca (2006).

\section{Financial Decisions in SME}

The financial organization of business is an important matter for any economy, Fazzari \& Athey (1987) point out that a financial distribution is necessary to deal, with certain guarantees of success, the challenges of the current environment condition. However, in the case of SME, the lack of a planned financial composition is one of the major structural problems that limit their chances of survival and growth in the market, and do not allow them to access to adequate financing regarding cost conditions, term and maturity (Stiglitz, 2000).

The process that takes place in small and medium enterprises, to evaluate, select and allocate resources focuses on a major factor: the owner or manager (Hoffman, 1972 quoted by Landström, 1995). In this sense, experience, prejudices or personal preferences are elements that influence financial decisions. Byers \& Snack (2001) indicates that the capability and ability of the entrepreneur or manager are elements that become essential in decision making.

The decision making carried out in this type of businesses represents an important process (Spivey \& Mc Millian 1999). Good business, those that create economic value, are the result of sound financial decisions (investment, financing, and operation). However, bad financial decisions destroy value, because it threatens the continuity of SME due to the quality of the decisions, rather than external factors (Ross, Westerfield \& Jiordan, 2002).

\section{Economic Value Added}

The objective of financial decision making in the enterprise is to maximize the value of the enterprise and the shareholders (Damodaran, 2000). Based on the corporate financial theory, there are three ways to create value: establish better investment decisions, use a proper financing structure or implement optimal investment policy.

It has been observed that when an enterprise is unable to generate economic value added (EVA) is not attractive to investors, and it is at risk not to survive (Dilon, 1997). Value creation becomes not only a competitive element, but also a component of the survival of any enterprise, whether it is in startup, creation or full development. Laniado (2002) notes that the creation of value is represented by a series of activities involving the owner or shareholder to obtain a return that is positive and higher than what would get by another comparable alternative.

EVA is a statistic that attempts to assess the residual income; it has been studied for over a century by Alfred Marshall (Acuña, 2000). However, Stern and Shiely (2000) point out that it was in the eighties when this financial indicator was rediscovered, currently known as Economic Value Added (EVA).

The Economic Value Added is a statistic aimed to measure the value created or destroyed by an enterprise, unit or department and have been mentioned by several authors.

Stewart (1990) describes it as the net operating profit less the cost of all capital employed to produce that income. Stern and Shieley (2000) have expressed it as the profit that results after deducting the cost of capital invested to generate such profit. Amat (2000) explains it as the amount remaining after deducting from the income, all expenses, including the cost of capital and taxes.

The empirical researches on analysis techniques based on value creation, such as EVA, have focused on various aspects: in the decision making as an indicator of productivity and executive compensation, or as an indicator of financial performance to determine whether the enterprise creates or not the expected value (Biddle, Bown \& Wallacec 1997; Evans, 2000).

However, Hall (2000) notes that there are few research works that link variables that produce economic value added; and refers to financial decisions as the greatest impact elements. In this sense, Ortega \& Villegas (2004) studied the characteristics of SME in Mexico to assess how these companies create value.

In SME, EVA cannot be directly measured. However, it can be related to drivers such as investment decisions, financing, and operation, with the strategies that directly generate value for the enterprise (Amat, 2000).

Taking as a reference the foregoing, in the present research, EVA model was used to determine whether the strategies used by small and medium enterprises are oriented to generating economic value.

The components that generate value have been classified by Copeland, Koller \& Murria (1995) quoted by Hall (2000) at three levels: generic value, business unit and operating level. Amat (2000) shows that there are three primary strategies in trying to increase the economic value added and presented in table 1. 
Table 1. EVA Strategies

\begin{tabular}{|l|l|}
\hline Strategy & Determinants \\
\hline Investing in new projects with a greater return than the capital cost. & $\begin{array}{l}\text { Knowledge of the market. } \\
\text { Create new business opportunities. } \\
\text { Invest in cost reductions. }\end{array}$ \\
\hline Increasing profits without increasing capital. & $\begin{array}{l}\text { Increase sales. } \\
\text { Reduce costs. } \\
\text { Increased value added to increase the price. }\end{array}$ \\
\hline \multirow{3}{*}{ Reducing capital without reducing profits. } & $\begin{array}{l}\text { Reduce accounts receivable and extend the days of bills } \\
\text { to pay. } \\
\text { Increase inventory turnover. } \\
\text { Reduce property, plant and equipment }\end{array}$ \\
\hline
\end{tabular}

Source: own

The application of these strategies depends on each organization. Each incorporates elements that contribute to the creation of value; a person who runs the enterprise can observe, identify and reassess them so that strategies are selected and to monitor the actions that provide value. Financial decisions made by the management have a positive or negative effect on those factors that eventually affect the owner's or shareholder's wealth.

\section{Model and Research Hypothesis}

Figure 1 presents a conceptual model developed from the literature. The model assumes the relations of how financial decisions for investment, financing and operations relate to strategies that generate economic value added to the enterprise, such as: investing in new projects with higher returns than the cost of capital, increasing profits without increasing capital, reducing capital without reducing profit.

\begin{tabular}{|l|l|}
\hline $\begin{array}{l}\text { Investment Decisions } \\
\text { Accounts receivables } \\
\text { Inventories }\end{array}$ \\
$\begin{array}{l}\text { Fixed Assets } \\
\text { Intangible Assets } \\
\text { Others } \\
\text { Operation decisions } \\
\text { Price } \\
\text { Cost } \\
\begin{array}{l}\text { Differentiation of product } \\
\text { Differentiation of technology } \\
\text { Others } \\
\text { Financing Decisions } \\
\text { Own resources } \\
\text { External financing } \\
\text { Financing by suppliers } \\
\text { Others } \\
\text { 1. } \begin{array}{l}\text { Strategies to generate EVA } \\
\text { Reducing capital without } \\
\text { reducing profits. }\end{array} \\
\text { 2. Increasing profits without } \\
\text { increasing capital }\end{array} \\
\text { 3. Investing in new projects with a } \\
\text { return over the cost of capital }\end{array}$ \\
\hline
\end{tabular}

Figure 1. Model of financial decisions that create economic value added

\subsection{Hypothesis}

From the analysis of the various empirical researches, it is deducted that, in the context of SME, financial decisions are an essential factor for economic development, and the owner or manager focuses precisely on the realization of this critical process.

The owner or manager is the one who should lead the economic decisions to promote strategies that create economic value for the enterprise, and to achieve stability and development. 
This approach generates the following hypothesis: "There is a relationship between investment, operating and financing decisions taken by the owner or manager, and the creation of economic value added to the enterprise."

\section{Variables}

The variables used in the empirical analysis, which can lead to creating or destroying value to the enterprise in terms of EVA, are:

a) operative decisions, including all activities that must be performed to furnish a product or provide a service,

b) investment decisions, those which are taken to acquire the assets that the enterprise requires to operate,

c) financing decisions, referring to the way the enterprise gets the necessary resources for the procurement of assets.

Finally, the economic value added is the result of the basic strategies used by the owner or manager of SME to create or destroy value for the enterprise. The operationalization of the three types of decisions is presented in table 2.

Table 2. Indicators of the types of decisions that can create value in an enterprise

\begin{tabular}{|c|c|c|}
\hline \multicolumn{3}{|r|}{ Owner } \\
\hline Key & Decisions & Indicator \\
\hline $\mathrm{X}_{1.1}$ & Investment & $\%$ of the amount of resources invested in assets by type. \\
\hline$X_{1.2}$ & Operations & $\begin{array}{l}\% \text { of companies that had an increase in unit. } \\
\% \text { of companies that established strategies related to the price. } \\
\% \text { of companies that established strategies related to costs. } \\
\% \text { of companies that established product differentiation strategies. } \\
\% \text { of companies that established differentiation strategies based on technology. }\end{array}$ \\
\hline$X_{1.3 .}$ & Financing & $\begin{array}{l}\% \text { of companies using their own resources for financing. } \\
\% \text { of enterprises using external financing. } \\
\% \text { of enterprises using financing from suppliers }\end{array}$ \\
\hline \multicolumn{3}{|r|}{ 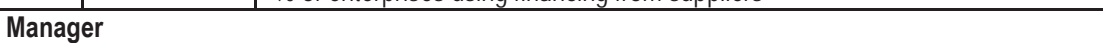 } \\
\hline $\mathrm{X}_{2.1}$ & Investment & $\%$ of the amount of resources invested in assets by type. \\
\hline$X_{2.2}$ & Operations & $\begin{array}{l}\% \text { of companies that had an increase in unit. } \\
\% \text { of companies that established strategies related to the price. } \\
\% \text { of companies that established strategies related to costs. } \\
\% \text { of companies that established product differentiation strategies. } \\
\% \text { of companies that established differentiation strategies based on technology. }\end{array}$ \\
\hline$X_{2.3 .}$ & Financing & $\begin{array}{l}\% \text { of companies using their own resources for financing. } \\
\% \text { of enterprises using external financing. } \\
\% \text { of enterprises using financing from suppliers }\end{array}$ \\
\hline
\end{tabular}

Source: Own creation.

\section{Delimitation of Population, Collection, Data Processing and Analysis}

The records of the Ministry of Economy of the state of San Luis Potosi for the year 2000 were used to get the information of the companies that make up the sample according to three inclusion criteria: 1) companies in the service, trade and industry sector, 2) labor force between 10 and 250 workers, and 3) have at least two years after starting operations.

The sampling type was probabilistic, random, and the sample size was calculated considering a confidence level of $95 \%$ with the allowed error of $5 \%$. The sample included 110 companies.

The statistic of contingency tables procedure was selected for the hypothesis test, in virtue of its adequacy for relationship analysis by evaluating the presence of effects. To confirm the relationship between the types of decisions and EVA, the statistical $X^{2}$ (chi - square) was used, and SPSS statistical package was used to process the data, as a decision criterion, the observed significance level ( $p$ value) was adopted and was contrasted with the significance level of the test $(\alpha=0.05)$. 


\section{Results}

\subsection{About the decisions taken by the owner of the enterprise.}

The hypothesis was tested using the statistical technique of contingency tables. Table 3 presents the values obtained from $X^{2}$ with its degrees of freedom and $(\alpha<0.05)$. This table shows the statistically significant results through $X^{2}$ with a significance level $(\alpha<0.05)$ to identify the relationship between financial decisions made by the business owner and value creation.

Table 3. Results of statistical analysis about decisions taken by the owner

\begin{tabular}{|l|c|c|c|}
\hline Type of decisions & $\begin{array}{c}\text { Pearson } \\
\text { Chi-Square }\end{array}$ & Df & $\begin{array}{c}\text { Asymp. } \\
\text { Sig. (2sided) }\end{array}$ \\
\hline Financing - Creation of EVA & 58,413 & 39 & .024 \\
Suppliers Collections problems (1) & 64.247 & 16 & .000 \\
\hline Operation- Creation of EVA & 45,466 & 16 & .000 \\
Organize purchases (2) & 27,630 & 16 & .035 \\
Collection problems (1) & 60,244 & 20 & .000 \\
Increase credit days (1) & 65,013 & 42 & .013 \\
Sell idle assets (1) & 31,979 & 20 & .044 \\
\hline Investment - Creation of EVA & 738.16 & 20 & .008 \\
Inventory - Improve customer satisfaction (2) & 31,667 & 20 & .047 \\
Others - Reduce raw material consumption (2) & & \\
Others - Eliminate errors in prices and orders (1) & & \\
Others - Coordination of suppliers (1) & &
\end{tabular}

Source: own

In Table 4, the proportion of decisions taken by the owner who generates economic value added is shown. The results show that, for owners of small businesses in San Luis Potosi (60\%), suppliers are their primary source of financing. $52.7 \%$ use operating decisions to create value and that their investment would be more common in inventories. $52.7 \%$ The owners perceived actions that created economic value for the enterprise.

Table 4. Percentage of decisions taken by the owner

\begin{tabular}{|l|c|}
\hline ITEM & Percentage \\
\hline Financing decisions & \\
Own resources & 54.3 \\
External & 40.9 \\
Suppliers & 60.0 \\
Operating decisions & 52.7 \\
Investment decisions & 56.2 \\
Inventory & 48.4 \\
Other & 52.7 \\
EVA strategy & \\
\hline
\end{tabular}

Source: own

\subsection{About the decisions taken by the enterprise manager}

Table 5 shows the statistically significant results through chi-square test with a significance level $(\alpha<0.05)$ to identify the relationship between decisions taken by the business, to manage, and value creation. 
Table 5. Results of statistical analysis to decisions made by the manager

\begin{tabular}{|l|c|c|c|}
\hline Type of decisions & $\begin{array}{c}\text { Pearson } \\
\text { Chi-Square }\end{array}$ & df & $\begin{array}{c}\text { Asymp. } \\
\text { Sig. (2sided) }\end{array}$ \\
\hline Financing - Creation of EVA & 57,261 & 30 & .020 \\
Own resources - Maintenance. (3) & 48,967 & 33 & .036 \\
External Financing_Organize purchases. (2) & 47,968 & 33 & .045 \\
External Financing_Maintenance (3) & 70,777 & 48 & .018 \\
\hline Investment - Creation of EVA & 15,733 & 8 & .046. \\
Inventory.- Increase credit days (1) & 26,667 & 12 E & 009 \\
Intangibles Assets - Maintenance (3) & & \\
Intangible Assets_Remove price and order error (1) & \\
1 = reducing capital without reducing profits. \\
$2=$ increasing profits without increasing capital \\
$3=$ investing in new projects with a return over the cost of capital.
\end{tabular}

Source: own

Table 6 shows the proportion of decisions made by the manager of the enterprise with regard to the relationship of the strategies that generate economic value added. The results show that, for managers of small businesses in San Luis Potosi, their main source of financing are own resources (45.7\%) and external financing (59.1\%). Regarding investment decisions, most frequently are inventory acquisition (43.8\%) and intangible assets (40\%). 47.3\% of managers perceived actions that create economic value for the enterprise.

Table 6. Percentage of decisions taken by the manager

\begin{tabular}{|l|c|}
\hline ITEM & Percentage \\
\hline Financing Decisions. & \\
Own resources & 45.7 \\
External & 59.1 \\
Investment decisions & 43.8 \\
Inventories & 40 \\
Intangible Assets & 47.3 \\
EVA Strategies & \\
\hline
\end{tabular}

\section{Source: own}

The results described above, show that both, the owner and the manager make decisions in order to create economic value, however, strategies differ from each other.

On one hand, the owners are financed primarily through its suppliers and orient their strategies to identify collection problems. The strategies related to operating decisions are oriented to organize purchases, perform activities in favor of the client (such as increasing credit days) and sell idle assets. Finally, it was noted that capital expenditures are based on the purchase of inventory, and strategies are oriented to improve customer satisfaction, better coordination with suppliers, reduce consumption of raw materials, and eliminate errors in pricing and orders.

However, the managers consider financing own resources and external resources and establish their actions oriented to the maintenance of the enterprise and the purchasing organization. In regard to operating decisions, do not perform actions that create economic value. Finally, their investments are focused on intangible assets and inventories, and their strategies are oriented to training for the maintenance of the enterprise and to remove errors in pricing and orders.

The results indicate that there is sufficient evidence to reject $\mathrm{H}_{0}$ (from the perspective of the owner or manager, there is no relationship between investment decisions, operation and financing, and the creation of economic value added of the enterprise) and in this case it is confirmed that the financial decisions are crucial to create value for the enterprise.

\section{Conclusions}

In general, the objective and hypothesis posed in this study were accomplished, as it provided empirical evidence to: 
1. Determine that the owners and managers of small and medium enterprises, under study in this research, believe that financial decisions are a tool to promote growth in the business and increase shareholder value.

2. Show that the owners and managers while making financial decisions their purpose is to generate economic value, however, the strategies differ according to the estimations of each one.

3. Show, from the obtained results, the need for more strategies that create economic value for the enterprises. However, it is important to note that the generation of economic value requires owners and managers to be willing and committed to guiding their decisions (financing, investment, and operations) to actions that create value.

A similar conclusion was obtained by Calva (2002), which states that the measurement of economic value creation in small and medium enterprises should begin by investigating whether the enterprise generates actions that influence the economic value.

Alongside there is the conclusion of Hall (2000), who ascertains using the EVA model that enterprises generate strategies that create value, so too exposed by Laniado (2002) who noted that the need for development and assessment of measurable strategies that drive value based on a meter adopted to create economic value for the enterprise.

The results make clear that owners and managers orient in a different way the actions that create value. It is consistent with the findings of studies of (Wales \& Blackburn, 1990), indicate that the gain of the enterprise depends on the ability of the owner or manager to take decisions and, based on them, set actions on the stated targets of the enterprise.

This work helps to strengthen, theoretically and empirically, the creation of economic value, centered on the analysis of small and medium enterprises in the trade, industry and service sector, and mainly considers the creation of economic value as a strategically valuable resource for sustaining a competitive advantage for this critical area.

\section{References}

Acuña, G. (2000). Eva. Valor Económico Agregado. <http://www.uch.edu.arl>

Amat, O (2000). EVA. Un nuevo enfoque para optimizar la gestión, motivar y crear valor. Spain. Gestión 2000

Biddle, G., Bowen, R. and Wallace, J. (1997). Does EVA beats earnings? Journal of Accountings and Economics, 24, 301-336.

Byers, T and Snack T. (2001). Strategic decision-making in small businesses within the leisure industry. Journal of Leisure Research, $33,121-13$.

Calva, A. (2002) Creación de Valor Económico de las empresas en México. <http://www.acus.com.mx> (Accessed october 28, 2005).

Damodaran, A. (2000). Investment Valuation: Tools and Techniques for Determining the Value of Any Asset. John Wiley \& Sons, Nueva York, 385-390.

Dilon, R. (1997). Eva as a financial metric: Atributes, utilization, and relationship to Practice \& Education 7 1-10.

Evans, J. (2000). An Examination of Economic Value Added and Executive Compensation Asian Review of Accounting, 2, 1-18.

Fazzari, Steven M \& Athey, Michael J, (1987). Asymmetric Information, Financing Constraints, and Investment," The Review of Economics and Statistics, MIT Press, 69, 481-87.

Gales, L. M. \& Blackburn, R. (1990). An analysis of the impact of supplier strategies and relationships on small retailer actions, perceptions, and performance. Entrepreneurship Theory \& Practice, 15, 7-21.

Hall, J. (2000) Dissecting Eva: the value drivers determining the shareholder value of industrial companies. Social Science Research. 4, 253-268.

Kadosca, G. (2006) Research of Competitiveness Factors of SME. Acta Polytechnica Hungarica 3(4), 71-84.

Landström, H. (1995). The relationship between private investors and small firms: an agency theory approach. Entrepreneurship \& Regional Development, 4, 199-223.

Laniado, D. (2002). Creación de Valor en las Empresas: El Papel de las Finanzas y la Gestión. Comercio Exterior 1-14

Ochoa (2002) La Determinación Análisis de Decisiones, Instituto Panamericano de alta dirección de empresa. <http://www.ipade.mx>

Ortega \& Villegas (2004) Valuation of Small and Medium Enterprises (SME) in México Revista Iztapalapa. <www.sase.org/conf2004l papers/ochoa-hernandez.pdf> (Accessed november 24, 2005).

Ross, S., Westerfield, R., \& Jiordan, B. (2002). Fundamentals of Corporate Finance USA; McGraw-Hill.

Roztocki, N. \& LaScola, K. (2000). EVA for Small Manufacturing Companies. International Management Conference in Las Vegas. Society for Advancement of Management (SAM.) March 28-30, Las Vegas, Nevada.

Secretaría de Economía (2000) <http://www.economia.gob.mx/> (Accessed october 28, 2005).

Spivey, M. F. \& McMillan, J. J. (1999). Using the edwards-bell-ohlson model to value small and entrepreneurial type businesses. Annual Meeting. American Accounting Association. August 3-6. Honolulu, Hawai.

Stern, J. \& Shiely, J. (2000). El reto el EVA. Spain. Gestión 2000.

Stewart (1990). The Quest for Value. USA: Harper Business.

Stiglitz, (2000). Credit Rationing in markets with imperfect information. American Economic Review, 3, 393-340. 